Revista Brasileira de Agricultura Irrigada v.11, nº.5, p. 1738 - 1746, 2017

ISSN 1982-7679 (On-line)

Fortaleza, CE, INOVAGRI - http://www.inovagri.org.br

DOI: $10.7127 /$ rbai.v11n500792

Protocolo 792.17 - 23/05/2017 Aprovado em 31/08/2017

\title{
IMPACT OF IRRIGATION AND NITROGEN FERTILIZATION ON THE ENERGY BALANCE AND ENERGY RETURN ON INVESTMENT OF JATROPHA PRODUCTION
}

\author{
Otávio Neto Almeida Santos ${ }^{1}$, Irineu Pedro de Sousa Andrade ${ }^{2}$, Bruno Patias Lena ${ }^{3}$, \\ Marcos Vinícius Folegatti ${ }^{4}$, Adriano Valentim Diotto ${ }^{5}$, Thiago Libório Romanelli ${ }^{6}$
}

\begin{abstract}
The aim of this research was to perform the energy analysis of Jatropha in two water management (full irrigation and rainfed) and four levels of nitrogen fertilization: 150\% (N150), $100 \%$ (N100), 50\% (N50), and 0\% (N0) of the fertilization recommendation for the crop. The study was developed in the experimental field area located at Piracicaba/SP, Brazil, during the third growing season of Jatropha. Material and energy flow, energy balance (EB), and the energy return on investment (EROI) were determined for all water and nitrogen levels. The component that most contributed as energy input were fuels for all conditions (17.71 GJ ha-1). Among all the treatments, the highest energy incorporation (37.48 $\left.\mathrm{GJ} \mathrm{ha}^{-1}\right)$ was observed in the N150 under irrigation. The increase for nitrogen applied, along with the irrigation usage, resulted in higher fruit yield and consequently input energy, despite the need for a greater energy investment. Without counting the residues in the analysis, only the N150 under irrigation was energetically efficient, presenting EROI of 1.04. Considering the residues, N150 and N100 with irrigation presented EROI of 1.15 and 1.06, respectively. Irrigation promoted an increase of 52, 63, 34 and 203\% in EROI for fertilization levels N150, N100, N50, and N0, respectively.
\end{abstract}

Keywords: Energy analysis, sustainability, energy flow.

\section{IMPACTO DA IRRIGAÇÃO E ADUBAÇÃO NITROGENADA NO BALANÇO E VIABILIDADE ENERGÉTICA DO CULTIVO DO PINHÃO-MANSO}

\footnotetext{
${ }^{1}$ Universidade de São Paulo - USP, e-mail: otaneto@usp.br

2 Marechal Rondon College, e-mail: andradeps26@gmail.com

${ }^{3}$ Unicentro, e-mail: brunoplena@gmail.com

${ }^{4}$ Universidade de São Paulo - USP, e-mail: mvfolega@usp.br

${ }^{5}$ Universidade Federal de Lavras - UFLA, e-mail: adriano.diotto@deg.ufla.br

${ }^{6}$ Universidade de São Paulo - USP, e-mail: romanelli@usp.br
} 


\section{RESUMO}

O objetivo desta pesquisa foi realizar a análise energética do pinhão-manso em duas condições hídricas (irrigação plena e sequeiro) e quatro níveis de adubação nitrogenada: 150\% (N150), $100 \%$ (N100), 50\% (N50) e 0\% (N0) da recomendação de adubação para a cultura. O estudo foi desenvolvido no campo experimental localizado em Piracicaba/SP, Brasil, durante o terceiro ano de cultivo da cultura. A partir do fluxo material foi determinado o fluxo de energia, o balanço de energia (BE) e energy return on investment (EROI) para todas as condições. Os combustíveis foram os insumos que apresentaram a maior contribuição na energia de entrada para as oito condições $\left(17,71 \mathrm{GJ} \mathrm{ha}^{-1}\right)$. Dentre os tratamentos, a maior incorporação de energia foi observada na condição N150 sob irrigação (37.48 GJ ha-1). Os aumentos na quantidade de nitrogênio aplicado, juntamente com a presença da irrigação, proporcionaram maior produção de frutos e consequentemente de energia, apesar de necessitarem de um maior investimento energético. Sem contabilizar os resíduos na análise, apenas a condição N150 sob irrigação foi eficiente energeticamente, apresentando EROI de 1,04. Considerando os resíduos, as condições N150 e N100 com irrigação apresentaram EROI de 1,15 e 1,06, respectivamente. A irrigação promoveu aumento de cerca de 52, 63, 34 e 203\% no EROI para os níveis de adubação N150, N100, N50 e N0, respectivamente.

Palavras-chave: Análise energética, sustentabilidade, fluxo de energia.

\section{INTRODUCTION}

The increment of agricultural yield has intensified the use of fertilizer, pesticide, fuel and machinery (ANDREA et al., 2014), which contribute to the increment of energy input in the production system. However, most studies with energy balance from agricultural production system usually do not consider some important inputs, such as fuel used on many machinery activities (CRUSE et al., 2010; JOHANSSON et al., 2012; PIMENTEL, 1980). Moreover, the lack of information about crop development, water use, and nutrient cycling make it impossible to determine better management practices, which is an important factor to improve the energy balance (ACHTEN et al., 2007).

Jatropha curcas L. (Euphorbiaceae) is a perennial oilseed plant that hasbeen highlighted as an alternative source for renewable energy. Besides the recent increment of studies with this crop, there is few information about the energy sustainability, especially when considering the continuous and long-term production (FRIGO et al., 2008), and the effects of irrigation and fertilizer management on the energy balance (EB) and energy return on investment (EROI). In energy crops such as Jatropha, EB and EROI are appropriate indicators, since both input and output energy are adequate for energy assessment (VEIGA et al., 2015).

Both irrigation and nitrogen fertilization are directly associated to the yield increment from crops. Studies with Jatropha have demonstrated that the high amount of fertilizer and water from irrigation applied to the plants resulted in lower positive energy balance when compared to the production system under low resources (JORDAN et al., 2012; SANTOS, 2016). Furthermore, the use of end-product and co-products in energy analysis showed a positive energy balance for biodiesel production from Jatropha (PRUEKSAKORN; GHEEWALA, 2006).

In order to obtain the sustainability from a bioenergy programs, it is necessary a higher biofuel energy production than the energy consumed during the production process. Nitrogen fertilizer is associated to the high input energy due to its large energy expenditures during the production processes (FREITAS et al., 2013). Moreover, the effect of irrigation on the production system and the energy balance of Jatropha has not been fully investigated, yet. It is necessary, therefore, to identify both crop management techniques in terms of energetic efficiency, which will provide valuable 
information about the energetic feasibility of Jatropha cultivation.

Thus, the objective of this study was to determine the Jatropha energy balance from two water management and four nitrogen fertilizer levels.

\section{MATERIAL AND METHODS}

\section{Experimental site}

This study was developed during the third growing season of Jatropha in an experimental area located at Piracicaba, SP, Brazil ( $22^{\circ} 41^{\prime}$ 57' S, 47 38' 38” $\mathrm{W}$ and $530 \mathrm{~m}$ a.s.l.). Climate of this region is classified as a humid subtropical (Cfa) with precipitation concentrated at the summer season and dry winter. Soil was a clay, containing $57.1 \%$ clay, $20.9 \%$ silt and $22.0 \%$ sand, $1.4 \%$ organic matter content, and bulk density $1.4 \mathrm{~g} \mathrm{~cm}^{-3}$. It was evaluated four nitrogen (urea) levels, with 150 (N150), 100 (N100), 50 (N50), and $0 \%$ (N0), considering the fertilizing recommendation for Jatropha cultivation (FACT, 2010), and two water management, one irrigated by center pivot and other under rainfed condition, with total area of 1.0 and 0.5 ha, respectively. The amount of irrigation depth was determined by two weighing lysimeters installed in both irrigated and rainfed areas previously calibrated and used to perform Jatropha actual crop evapotranspiration.

\section{Energy efficiency indicators}

Two indicators were determined for the energy analysis: energy balance (EB) and energy return on investment (EROI), which were calculated by the equations (1) (ROMANELLI et al., 2012) and (2).

$$
\begin{aligned}
& E B=E_{o}-\sum E_{i} \\
& E R O I=E_{o} / \sum E_{i}
\end{aligned}
$$

where $E B\left(\mathrm{GJ} \mathrm{ha}^{-1}\right)$ is the energy balance, $E_{o}(\mathrm{GJ}$ $\left.\mathrm{ha}^{-1}\right)$ is the total energy output and $E_{i}\left(\mathrm{GJ} \mathrm{ha}^{-1}\right)$ is the total energy input, EROI - Energy Return On Investment (dimensionless).

\section{Material and Energy flow}

The total energy consumed (input) during the Jatropha production system (Ei) was calculated by accounting the entire technical itinerary of the operations in the third year of the Jatropha cultivation. Machinery and labor used on weeds, insects, and diseases control were accounted for input energy. Moreover, the sum of the energy coefficients corresponding to the correctives, fertilizers, fungicides, herbicides and insecticides used in each system was estimated, as well as the energy consumed by the direct or indirect use of irrigation.

Machinery and equipment mass depreciation were determined by equation 3 (ROMANELLI; MILAN, 2010), considering a tractor with $3,940 \mathrm{~kg}, 55 \mathrm{~kW}$ of gross engine power and 1,200 $\mathrm{h}$ of lifespan. The lifespan for the sprayer was considered 2,000 $\mathrm{h}$ and 1,500 $\mathrm{h}$ for the manual grass mower used in the weed control.

$$
M D=M^{*} E E_{m} /(E L * E F C)
$$

where $M D\left(\mathrm{MJ} \mathrm{ha}^{-1}\right)$ is machinery depreciation, $M(\mathrm{~kg})$ is machinery mass, $E E_{m}$ is the embodied energy of machinery $\left(\mathrm{MJ} \mathrm{kg}^{-1}\right), E L$ (h) is machinery effective life (or lifespan) and EFC is effective field capacity (ha $\mathrm{h}^{-1}$ ).

Fuel consumption for each operation was calculated by equations 4 and 5 (ROMANELLI; MILAN, 2010).

$$
\begin{gathered}
C_{\text {hour }}=G P_{\text {eng }} * S C \\
E_{c}=\frac{C_{\text {hour }} * f c b^{*} H_{m}}{A}
\end{gathered}
$$

where $C_{\text {hour }}\left(\mathrm{L} \mathrm{h}^{-1}\right)$ is hourly consumption, $G P_{\text {eng }}$ $(\mathrm{kW})$ is engine gross power and $S C$ is a consumption factor $\left(0.163 \mathrm{~L} \mathrm{~kW}^{-1} \mathrm{~h}^{-1}\right.$ (MOLIN; MILAN, 2002), $E_{c}$ is energy from fuel consumption ( $\left.\mathrm{MJ} \mathrm{ha}^{-1}\right), f c b$ is fuel energy index (MJ L ${ }^{-1}$ ), $H_{m}$ is the amount of hours the machines worked in the year $\left(\mathrm{h} \mathrm{yr}^{-1}\right)$, and $A$ is cultivated area (ha).

Energy related to human labor was determined using the equation 6 .

$$
E_{\text {labor }}=\left(H_{y} * F_{\text {labor }}\right) / A
$$


where Elabor $\left(\mathrm{MJ} \mathrm{ha}^{-1}\right)$ is the embodied energy from human labor, $H_{y}(\mathrm{~h})$ is total hours from human labor, $F_{\text {labor }}\left(\mathrm{MJ} \mathrm{h}^{-1}\right)$ is the hourly energy requirement for human labor and $A$ (ha) is the area.

Energy input related to the consumption of fertilizers and chemicals (fungicides, herbicides, and insecticides) was determined by equations 7 and 8 (ROMANELLI; MILAN, 2005).

$$
\begin{gathered}
E_{l i}=\left(E_{c l} * i_{a} * V_{p} * Q\right) / V_{a} \\
E_{s i}=Q_{t} * E_{c s}
\end{gathered}
$$

where $E_{I l}\left(\mathrm{MJ} \mathrm{ha}^{-1}\right)$ is the enclosed energy on applied pesticides, $E_{c l}\left(\mathrm{MJ} \mathrm{L}^{-1}\right)$ is the enclosed energy of a liquid input, $i_{a}(\%)$ is the concentration of active ingredient in the commercial product, $V_{p}(\mathrm{~L})$ is the used volume of the commercial product, $V_{a}(\mathrm{~L})$ is the volume to be applied and $Q\left(\mathrm{~L} \mathrm{ha}^{-1}\right)$ is the application rate, $E_{s i}$ is the enclosed energy in solid inputs $\left(\mathrm{MJ} \mathrm{ha}^{-1}\right), Q_{t}\left(\mathrm{~kg} \mathrm{ha}^{-1}\right)$ is the quantity of input applied per hectare and $E_{c s}\left(\mathrm{MJ} \mathrm{kg}^{-1}\right)$ is the energy content of a solid input.
For the irrigated area, total energy input by irrigation system usage was determined by direct energy used to pump water for the irrigation system (equation 9) (ROMANELLI; MILAN, 2005) and indirect embodied energy from irrigation (equation 10) (DIOTTO et al., 2014), considering a center pivot with 20 year of lifespan with $260 \mathrm{~m}$ long main line and the system flow was $0.01 \mathrm{~m}^{3} \mathrm{~s}^{-1}$. It was considered an area of 10 ha to simulate the pumping power requirement $(14.4 \mathrm{~kW})$, since this area can be considered a minimal to return the investment on a center pivot.

$$
E_{i r r}=\left(C_{e e} * G P * H_{d} * N_{d}\right) / A
$$

where $E_{\text {irr }}\left(\mathrm{MJ} \mathrm{ha}^{-1} \mathrm{yr}^{-1}\right)$ is the direct energy used by irrigation system, $C_{e e}\left(\mathrm{MJ} \mathrm{kW}^{-1} \mathrm{~h}^{-1}\right)$ is the energy index of electric energy, $G P(\mathrm{~kW})$ is the electric engine gross power, $H_{d}\left(\mathrm{~h} \mathrm{~d}^{-1}\right)$ is the hour used per day with the system on, $N_{d}$ is the number of days with irrigation per year $\left(\mathrm{d} \mathrm{yr}^{-1}\right)$ and $A$ is the irrigated area (ha). The energy index considered for each material used is presented in Table 1.

$$
E E_{\text {pivot }}=\left(\frac{251.36 * A^{-0.501}}{U L}\right)+\left[\frac{(0.75 * Q+0.0076) * L+0.044 * P}{A}\right]
$$

where $E E_{\text {pivot }}\left(\mathrm{GJ} \mathrm{ha}^{-1} \mathrm{yr}^{-1}\right)$ is the indirect embodied energy from center pivot, $U L(y r)$ is the irrigation system lifespan, $Q\left(\mathrm{~m}^{3} \mathrm{~s}^{-1}\right)$ is the irrigation system total flow, $L(\mathrm{~m})$ is the main line length and $P(\mathrm{kWh})$ is the pump gross power.

Table 1. Energy index for inputs applied for Jatropha crop system.

\begin{tabular}{cccc}
\hline Material & Unit & Energy Index (MJ unit $\mathbf{~}^{\mathbf{1}}$ ) & Reference \\
\hline Machinery & $\mathrm{kg}$ & 68.90 & Fluck and Baird (1982) \\
Fuel & $\mathrm{L}$ & 38.55 & Ulbanere (1988) \\
Labor & $\mathrm{h}$ & 2.2 & Serra et al. (1979) \\
Nitrogen & $\mathrm{kg}$ & 50.28 & Melo et al. (2007) \\
Phosphor & $\mathrm{kg}$ & 9.30 & Shapouri et al. (2003) \\
Potassium & $\mathrm{kg}$ & 6.77 & Melo et al. (2007) \\
Micronutrients & $\mathrm{kg}$ & 1.67 & Ferraro Júnior (1999) \\
Insecticides & $\mathrm{L}$ & 184.7 & Pimentel (1980) \\
Fungicides & $\mathrm{L}$ & 97.10 & Pimentel (2009) \\
Glyphosate & $\mathrm{L}$ & 261.6 & Shapouri et al. (2003) \\
Electric energy & $\mathrm{kWh}$ & 11.8 & Pimentel (1980)
\end{tabular}

Mature fruits were collected throughout the harvest period, which occurred between December 2013 and March 2014. To convert the total yield to output energy, the energy index of 21.2 $\mathrm{MJ} \mathrm{kg}^{-1}$ (OPENSHAW, 2000) was used for a whole fruit of Jatropha with bark and $8 \%$ of 
humidity. From this value, the use of residues was also considered, with a $10 \%$ increase in energy production.

\section{RESULTS AND DISCUSSION}

The total embodied energy for the field implantation was 19.6 GJ ha-1, and this value can be considered for 20 years of Jatropha cultivation. Thus, for every year, a value of 0.97 $\mathrm{GJ} \mathrm{ha}^{-1} \mathrm{yr}^{-1}$ was adopted for the inputs invested.
The total embodied energy fluctuation was influenced by irrigation and nitrogen applied. In general, the irrigated area showed higher energy input in comparison to the rainfed condition (Table 2). The higher contribution of irrigation on total energy was also observed by Frigo et al. (2008) with Jatropha and by Diotto and Irmak (2016) with corn. The highest energy input was observed for N150 and under irrigation (37.48 GJ ha-1), while the lowest value was obtained for N0 under rainfed conditions (25.71 GJ ha-1).

Table 2. Energy input and output $\left(G J \mathrm{ha}^{-1}\right)$, energy balance (EB, GJ ha $\left.{ }^{-1}\right)$ and energy return on investment (EROI, GJ ha ${ }^{-1}$ ) from all components used for Jatropha production.

\begin{tabular}{|c|c|c|c|c|c|c|c|c|c|}
\hline & & \multicolumn{4}{|c|}{ Irrigated } & \multicolumn{4}{|c|}{ Rainfed } \\
\hline & & No & N50 & N100 & N150 & No & N50 & N100 & $\mathrm{N} 150$ \\
\hline \multirow{8}{*}{ Input } & Fuel & 17.71 & 17.71 & 17.71 & 17.71 & 17.71 & 17.71 & 17.71 & 17.71 \\
\hline & Electric energy & 2.11 & 2.11 & 2.11 & 2.11 & - & - & - & - \\
\hline & Labor & 0.59 & 0.59 & 0.59 & 0.59 & 0.59 & 0.59 & 0.59 & 0.59 \\
\hline & Machinery & 3.24 & 3.24 & 3.24 & 3.24 & 3.24 & 3.24 & 3.24 & 3.24 \\
\hline & Fertilizers and Chemicals & 3.19 & 4.93 & 6.66 & 8.39 & 3.19 & 4.93 & 6.66 & 8.39 \\
\hline & Irrigation system & 4.44 & 4.44 & 4.44 & 4.44 & - & - & - & - \\
\hline & Implantation & 0.97 & 0.97 & 0.97 & 0.97 & 0.97 & 0.97 & 0.97 & 0.97 \\
\hline & Total input & 32.28 & 34.01 & 35.74 & 37.48 & 25.71 & 27.45 & 29.18 & 30.92 \\
\hline \multirow{3}{*}{ Output } & Jatropha fruit & 20.83 & 30.85 & 34.34 & 39.14 & 5.48 & 18.58 & 17.23 & 21.26 \\
\hline & Residues & 2.08 & 3.08 & 3.43 & 3.91 & 0.55 & 1.86 & 1.72 & 2.13 \\
\hline & Total output & 22.91 & 33.93 & 37.77 & 43.06 & 6.02 & 20.44 & 18.95 & 23.39 \\
\hline \multirow{2}{*}{ EB } & Without residues credits & -11.45 & -3.16 & -1.41 & 1.66 & -20.23 & -8.87 & -11.95 & -9.65 \\
\hline & With residues credits & -9.36 & -0.08 & 2.03 & 5.57 & -19.69 & -7.01 & -10.23 & $-7,52$ \\
\hline \multirow{2}{*}{ EROI } & Without residues credits & 0,65 & 0,91 & 0.96 & 1.04 & 0.21 & 0.68 & 0.59 & 0.69 \\
\hline & With residues credits & 0.71 & 0.99 & 1.06 & 1.15 & 0.23 & 0.74 & 0.65 & 0.76 \\
\hline
\end{tabular}

N0 (0\% N), N50 (50\% N), N100 (100\% N) and N150 (150\% N).

Under irrigation, fruits yield was 1846.3, 1619.7, 1455.0, and $982.5 \mathrm{~kg} \mathrm{ha}^{-1}$ in N150, N100, N50, and N0 treatments, respectively. In rainfed conditions, yield of jatropha fruits was lower in relation to the irrigated area where yields were 1003.0, 812.5, 876.3, and $258.3 \mathrm{~kg}$ ha $^{-1}$ in N150, N100, N50, and N0 treatments, respectively. Considering the Jatropha yield and total energy input, EB was negative in all treatments when the credits from residues were not computed, except in condition N150 irrigated (1.66 GJ ha-1). However, when considering the residues credits, N100 under irrigation also presented positive EB. Similarly, EROI was greater than 1 in treatment N150 irrigated without assuming residues credits. The addition of the residues in the accounting caused increase in EROI in all treatments, however, showed energetic viability $(E R O I \geq 1)$ only in treatments N150 and N100 under irrigation (Table 2). For the rainfed condition and all nitrogen fertilizer treatments, EROI was less than 1 , even when considering the residue credits. For both irrigated and rainfed conditions, the highest and lowest EROI values were observed in treatments N150 and N0, respectively. These results show the high influence of nitrogen fertilization together with irrigation on the energetic profitability of the Jatropha production system (PRUEKSAKORN; GHEEWALA, 2006).

Observing all the energy inputs in the experiment (Table 2), it was verified that the fuel consumption was the input that most contributed in the incorporated energy in both 
water managements conditions (17.71 GJ ha-1). High values of fuel utilization shows a strong dependence on fossil fuel in bioenergy crops (Jordan et al., 2012).

The presence of irrigation system was the main reason for the difference in total energy input between irrigated and rainfed treatments due to the indirect energy embodiment by the center pivot irrigation system and the direct electric energy used to pump and pressurize the water. The total energy input by the irrigation system was $6.55 \mathrm{GJ}^{\mathrm{ha}}{ }^{-1}$, with $4.44 \mathrm{GJ} \mathrm{ha}^{-1}$ represented by the indirect use of the irrigation system and $2.11 \mathrm{GJ} \mathrm{ha}^{-1}$ by the electric energy for the operation of the pump. Irrigation represented $20.4,19.3,18.3$, and $17.5 \%$ of the total energy input for the N0, N50, N100, and N150 treatments, respectively (Figure 1).
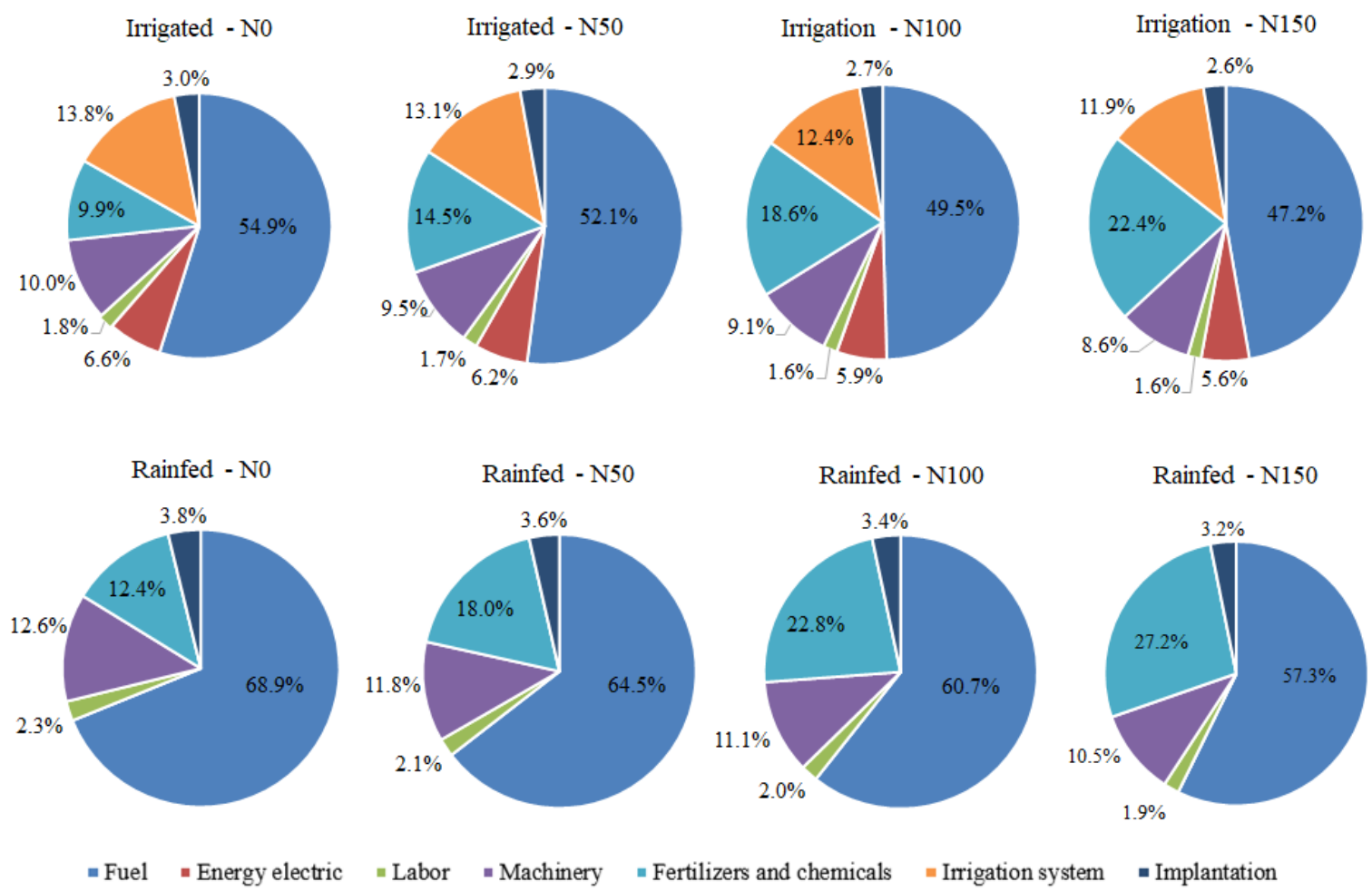

Figure 1. Percentage of the total energy input distribution in farm operations.

The use of chemicals and fertilizers corresponded the second highest energy inputs in the Jatropha cultivation system. Increasing $\mathrm{N}$ applied promoted higher energy consumption, and these values were higher for the N150 treatments in each water management condition (Table 2). These results are mainly explained by the high energy index of nitrogen (50.28 $\mathrm{MJ} \mathrm{kg}^{-}$ ${ }^{1}$ ). The energy used by the nitrogen application ranged from $9.9 \%$ (N0) to $22.4 \%$ (N150) and from $12.4 \%(\mathrm{~N} 0)$ to $27.2 \%$ (N150) in irrigated and rainfed treatments, respectively (Figure 1).

However, this higher energy investment did not have a negative effect on EROI, since the higher amounts of nitrogen along with the presence of irrigation may have influenced the increase in productivity and consequent of the total value of energy produced (energy output). Gomes et al. (2013), in a study with common bean, also observed increment of EROI with plant under irrigated condition. In this study, irrigation promoted an increase of $52,63,34$, and 203\% in EROI for fertilization levels N150, N100, N50, and N0, respectively.

According to Cavalett \& Ortega (2010), Macedo et al. (2008), and Gomes et al. (2013), the highest energy consumption in agricultural phase or the on-farm activities is expected. It emphasizes the importance of improving the crop production system by implementing and adequate crop management such as fertilizer and water use efficiency. Despite the small energy profit observed in this study, it is important to use more efficient management practices with 
less dependence on fossil energy sources to improve this index. For nitrogen, the use of green fertilization, symbiotic fixation (GAZZONI et al., 2005), and domestic sewage as a source of $\mathrm{N}$ can contribute to the energy inputs and guarantee the energy profitability for biofuel production (FREITAS et al., 2013).

\section{CONCLUSIONS}

The fuel consumption was responsible for the largest energy input in all treatments.

The energy balance was positive for treatment with $150 \%$ of nitrogen and under irrigated condition, even without considering the residues.

The residues accounting for energy production promoted an increase of EROI, but this value was higher than 1 only for the N150 and N100 treatments under irrigated condition.

\section{ACKNOWLEDGEMENTS}

The authors are grateful to Research Support Foundation of the State of São Paulo (FAPESP) and National Council of Technological and Scientific Development (CNPq) for financial support.

\section{REFERENCES}

ACHTEN, W.M.J.; MATHIJS, E.; VERCHOT, L.; SINGH, V.P.; AERTS, R.; MUYS, B. Jatropha biodiesel fueling sustainability? Biofuels, Bioproducts and Biorefining, v.1, p. 283-291, 2007.

ANDREA, M.C.S.; TIEPPO, R.C.; GIMENEZ, L.M.; POVH, F.P.; KATSMAN, T.J.; ROMANELLI, T.L. Energy demand in agricultural biomass production in Parana state, Brazil. Agricultural Engineering International: CIGR Journal, special issue, p.42-51, 2014.

CAVALETT, O; ORTEGA, E. Integrated environmental assessment of biodiesel production from soybean in Brazil. Journal of Cleaner Production, v.18, p.55-70, 2010. doi:10.1016/j.jclepro.2009.09.008.

CRUSE, M.J.; LIEBMAN, M.; RAMAN, D.R.; WIEDENHOEFT, M.H. Fossil energy use in conventional and low-external-input cropping systems. Agronomy Journal, v.102, p.934-941, 2010.

DIOTTO, A.V.; IRMAK, S. Embodied Energy and Energy Return on Investment Analyses in Maize Production for Grain and Ethanol under Center Pivot, Subsurface Drip, and Surface (Furrow) Irrigation with Disk Tillage and NoTill Practices. Transactions of the ASABE, Saint Joseph, v.59, p.873-884, 2016. doi:10.13031/trans.59.11331.

FACT Foundation. The Jatropha handbook, from cultivation to application. Eindhoven: FACT Foundation, 2010. 117 p.

FERRARO JÚNIOR, L.A. Proposição de método de avaliação de sistemas de produção e de sustentabilidade. 1999. 132f. Dissertação (Mestrado em Fitotecnia) - Universidade de São Paulo, Piracicaba.

FLUCK, R.C.; BAIRD, C.D. Agricultural energetics. Gainesville: University of Florida, Agricultural Engineering Department, Institute of Food and Agricultural Sciences, 1982. 197p.

FREITAS, C.A.S.; SILVA, A.R.A.; BEZERRA, F.M.L.; ANDRADE, R.R.; MOTA, F.S. Análise energética do girassol irrigado com esgoto doméstico tratado para produção de biodiesel. Revista Caatinga, v.26, n.3, p.62 - 72, 2013.

FRIGO, M.S.; BUENO, O.C.; ESPERANCINI, M.S.T. Análise energética da cultura de pinhãomanso (Jatropha curcas L.) em sistema de sequeiro: estudo de caso. Revista Energia na Agricultura, v.23, p.90-98, 2008.

GAZZONI, D. L. et al. Balanço energético das culturas de girassol e soja para produção de 
biodiesel. Biomassa e Energia, v. 2, n. 4, p. 259-265, 2005.

GOMES, E.P.; JORDAN, R.A.; MOTOMIYA, A.V.D.A.; PÁDUA, J.B.; BISCARO, G.A.; GEISENHOFF, L.O. Análise econômica e viabilidade energética da cultura do feijoeiro comum sob irrigação. Revista Brasileira de Engenharia Agrícola e Ambiental, v.17, p.835-842, 2013. doi:10.1590/S141543662013000800006.

JOHANSSON, T.B.; NAKICENOVIC, N.; PATWARDHAN, A.; GOMEZ-ECHEVERRI, L. Global Energy Assessment: Toward a Sustainable Future. Cambridge: Cambridge University Press, 2012. 1865 p.

JORDAN, RA; GOMES, EP; BISCARO, GA; MOTOMIYA, AVDA; GEISENHOFF, L. Impacto energético da irrigação por gotejamento no cultivo de mamona. Pesquisa Agropecuária Tropical, v. 42, p. 375-382, 2012. doi:10.1590/S1983-40632012000400005.

MACEDO, I.C; SEABRA, J.E.A.; SILVA, J.E.A.R. Greenhouse gases emissions in the production and use of ethanol from sugarcane in Brazil: The 2005/2006 averages and a prediction for 2020. Biomass and Bioenergy, v.32, p.582595 , 2008. doi:10.1016/j.biombioe.2007.12.006.

MELO, D.; PEREIRA, J.O.; SOUZA, E.G.; GABRIEL FILHO, A.; NÓBREGA, L.H.P.; PINHEIRO NETO, R. Energetic balance of soybean and corn production systems in a farm of the west of Paraná, Brazil. Acta Scientiarum. Agronomy, v. 29, n. 2, p. 173- 178, 2007.

MOLIN, J.P.; MILAN, M. Trator-implemento: dimensionamento, capacidade operacional e custo. In: GONÇALVES, J.L.M. Conservação e cultivo de solos para plantações florestais. Piracicaba: IPEF, 2002. p. 409-436.

OPENSHAW, K. A review of Jatropha curcas: an oil plant of unfulfilled promise. Biomass and Bioenergy, v.19, p.1-15, 2000. doi: 10.1016/S0961-9534(00)00019-2.
PIMENTEL, D. Energy inputs in food crop production in developing and developed nations. Energies, Paris, v.2, n.1, p.1-24, 2009. doi:10.3390/en20100001

PIMENTEL, D. Handbook of energy utilization in agriculture. Boca Raton: CRC Press, 1980, 496 p.

PRUEKSAKORN, K.; GHEEWALA, S.H. Energy and greenhouse gas implications of biodiesel production from Jatropha curcas L. In: PROCEEDINGS OF THE $2^{\text {nd }}$ JOINT INTERNATIONAL CONFERENCE ON "SUSTAINABLE ENERGY AND ENVIRONMENTS (SEE 2006), 2006, Bangkok. Anais eletrônicos... Bangkok, 2006. Disponível em: $<$ http://www.jgsee.kmutt.ac.th/see1/cd/file/E053.pdf > . Acesso em: 03 mai. 2017.

ROMANELLI, T.L.; MILAN, M. Material flow determination through agricultural machinery management. Scientia Agricola, v. 67, p. 375383, 2010. doi:10.1590/S010390162010000400001.

ROMANELLI, T.L.; NARDI, H.S.; SAAD, F.A. Material embodiment and energy flows as efficiency indicators of soybean (Glycine max) production in Brazil. Engenharia Agricola, v. 32, p. 261-270, 2012. doi: 10.1590/S010069162012000200006

ROMANELLI, TL; MILAN, M. Energy balance methodology and modeling of supplementary forage production for cattle in Brazil. Scientia Agricola, v. 62, p. 1-7, 2005. doi:10.1590/S0103-90162005000100001.

SERRA, G. E.; HEEZEN, A. M.; MOREIRA, J. R.; GOLDEMBERG, J. Avaliação da energia investida na fase agrícola de algumas culturas. Brasília: Secretaria de Tecnologia Industrial, 1979. 86p.

SHAPOURI, H.; DUFFIELD, J. A.; WANG, M. The energy balance of corn ethanol revisited. 
Transactions of the ASAE, v.46, n.4, p. 959968, 2003. doi:10.13031/2013.13951

SANTOS, O.N.A. Irrigação e tipos de poda no cultivo de pinhão-manso em Piracicaba, SP. Piracicaba. 2016. 118f. Dissertação (Mestrado em Engenharia de Sistemas Agrícolas) Universidade de São Paulo, Piracicaba.

ULBANERE, R.C. Análise dos balanços energético e econômico relativa à produção e perda de grãos de milho no Estado de São Paulo. 1988. 127f. Tese (Doutorado em Agronomia) - Universidade Estadual Paulista, Botucatu.

VEIGA, J.P.S.; ROMANELLI, T.L.; GIMENEZ, L.M.; BUSATO, P.; MILAN, M. Energy embodiment in Brazilian agriculture: an overview of 23 crops. Scientia Agricola, v. 72, p. 471477, 2015. 